\title{
Lessons from 50 years describing and classifying fungi
}

David L. Hawksworth

Honorary President, International Mycological Association

Comparative Plant and Fungal Biology, Royal Botanic Gardens, Kew, Surrey, TW9 3DS, UK; Department of Life Sciences, The Natural History Museum, Cromwell Road, London, SW7 5BD, UK; Jilin Agricultural University, Changchun, Jilin Province, 130118 China.

Corresponding authorEmail: d.hawksworth@kew.org

(Submitted on October 10, 2020; Accepted on November 15, 2020)

\section{ABSTRACT}

This contribution reflects on ten lessons learned during the 50 years since the author first described a new fungal taxon. These are: (1) It is easier to describe something as new than to find out if it has already been described; (2) Examine as many specimens and cultures as you can; (3) Study as many characters with as many techniques as possible - in the field as well as the laboratory; (4) Formulate species concepts before examining types; (5)Taxonomic ranks are a human construct; (6) Make the international Code work for you; (7) Always deposit isotypes and preserve vouchers for unusual records; (8) Check measurements of microscopic features; (9) Do not be afraid to challenge current ideas and present new hypotheses; and (10) Do not submit your paper right away and choose an appropriate journal. It is hoped these may prove of value to those in early stages of a career in fungal systematics.

Keywords: Cultures, Good practice, International Code of Nomenclature, Nomenclature, Species concepts, Systematics, Taxonomy, Type specimens, Voucher specimens

\section{INTRODUCTION}

The year 2018 marked the fiftieth anniversary of my first description of a novel fungal taxon - in 1968, when I was just 22 years old and in the second year of my $\mathrm{PhD}$ at the University of Leicester. This was a previously un-named chemotype of Ramalina subfarinacea found to produce only salazinic acid in the medulla, and I named it var. salazinica (Hawksworth, 1968). The compound was identified by paper chromatographic comparison with a pure sample of the acid and by microcrystal tests, and the taxon is now subsumed in $R$. farinacea; that species proved to have more variability in natural products than appreciated at that time. Looking back, I realize how naïve I was, and wish I had known then what I know half a century later, not only with regard to the fungi, but how to approach systematic research in general, and bring it to fruition.

There was not much guidance on how to proceed in fungal taxonomy around at the time, apart from Bisby's little book (Bisby, 1945), which I later had the task of revising and extending (Hawksworth, 1974). Fortunately, however, much could be gleaned from introductions to systematics on other groups of organisms and the then recently-published text on angiosperm taxonomy by Davis and Heywood (1963) was most illuminating. At Leicester I was the first to work on the taxonomy of lichen-forming fungi, but was fortunate that there were several leading world-class systematists on the staff at that time dealing with plants (Arthur O. Chater, "Tom" G. Tutin, and David M. Moore), bacteria (Peter H.A. Sneath), and fossil crustacea (Peter C. Sylvester-Bradley). The ability to learn from such luminaries was a massive help and inspiration to me, and in the years that followed I also benefitted from working closely with many other mycological and non-mycological systematists.

Mycologists who are interested in taxonomy, then and today, often work in isolation, and obtaining guidance or authoritative information can be both difficult and timeconsuming, even in the era of the worldwide web. I have unfortunately not had the time to do an update of my now rather obsolete handbook (Hawksworth, 1974), but felt it might be of interest to pick out ten lessons that I have learnt as a fungal systematist over the half-century since I started that journey professionally. These could perhaps be viewed as "memes" to be passed to a new generation, as I learnt from the elders I benefitted from in my early days.

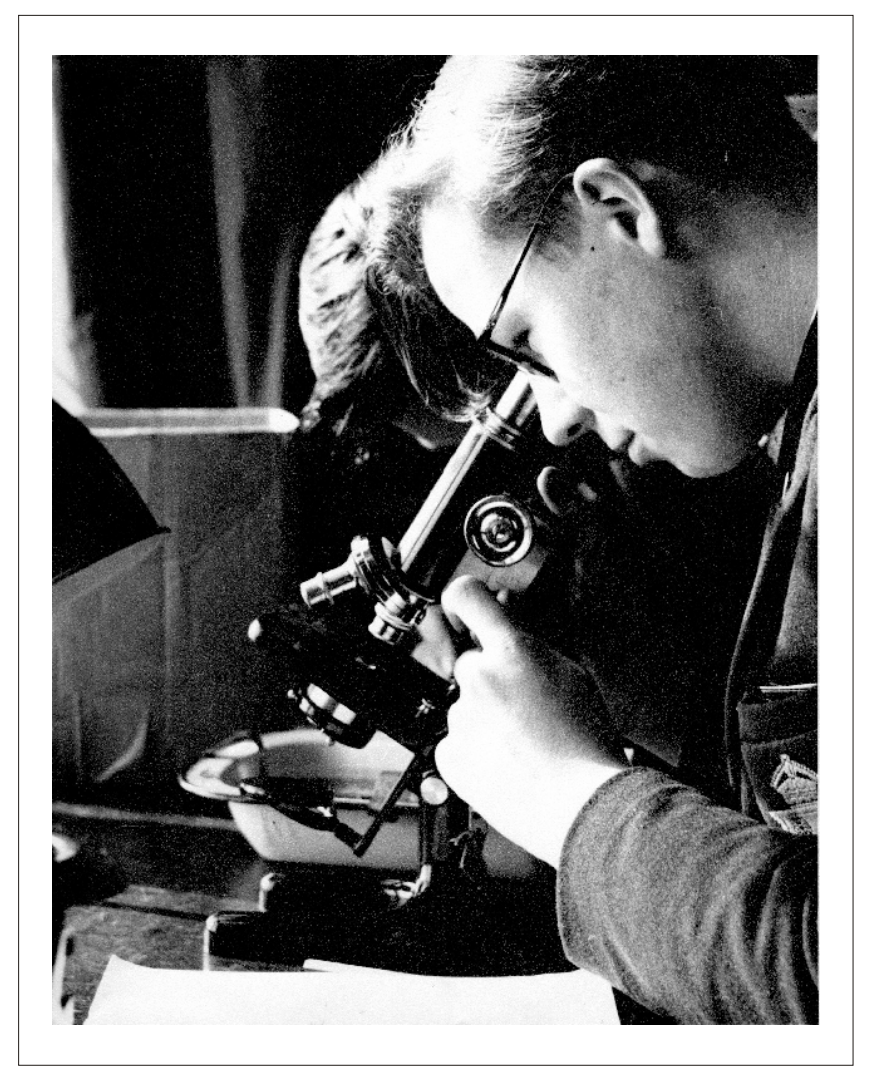

Fig. 1. The author at the microscope as a 6th Former at the Herbert Strutt Grammar School, Belper, Derbyshire, UK, in 1963. 


\section{TEN LESSONS}

Lesson 1: It is easier to describe something as new than to find out if it has already been described

If you have a fungus that does not appear to have a name from the literature at hand, it is possible to make a description, provide a name, and designate it as the type of that name. But can you be really sure that it has not already been named at some point over the last 270 years? If you look at a monograph, or species entries in the Species Fungorum database (http://www.speciesfungorum.org/), you will soon see that many species have extensive lists of synonyms. Indeed, an analysis of published species names indicates that on an average each single accepted species has been named 2.5 times; the number of available species names is over double that of the currently accepted species (Hawksworth and Lücking, 2018).

You must ask yourself if you want to be responsible for introducing a name that will be in the literature for all time and add to the baggage to burden all future generations of researchers. Once validly published, names cannot be removed from the world's databases, even if they are no longer accepted or failed to meet the internationally accepted criteria for validity or availability. I find it somewhat embarrassing that I have been involved in adding, either alone or with colleagues, 896 scientific names over the 50 years since my first one. I have come to think of the author citations, often added after scientific names, as an attribution of blame for introducing a name rather than an accolade to the person(s) responsible for its introduction; I now only use them in formal taxonomic and nomenclatural presentations, and delete them wherever possible from papers I edit. If more information is wanted about a fungal name, it is now so easy to just click through to Index Fungorum (http://www.index fungorum.org/Names/Names.asp).

If you have what seems at first to be a new genus or species, it is essential to check out the names already existing in the family or genus, respectively - something that is so much easier today than before because of the existence of the freely-available Index Fungorum database (http://www.indexfungorum.org/). In doing this it is necessary also to consider names that may have been introduced under sexually and asexually typified genera, or in genera that formerly had much wider circumscriptions than the concepts of today.

This also applies to when revisions are being made, when all available names need to be considered to determine which should be applied to a particular taxon. Earlier names can exist in places where it would never seem logical to search, and this has caught me out on several occasions. For example, five years after I published on Nectria heterospora (Hawksworth and Booth, 1976), I found that the fungus had first been described in the asexually typified genus Diplodia, the ascospores having been mistaken for conidia in 1874 (Hawksworth, 1981)! The host or substrate can be a great help in eliminating names, but that is not infallible either as I have found in my work on lichenicolous fungi (ones that only grow on lichens). I have even come across instances where a species was described but the fact that the fungus in question was growing on a lichen was overlooked. For example, on a visit to the Farlow Herbarium (FH) in the USA, and eight years after I had described a new genus growing on certain foliicolous lichens (Ascohansfordielliopsis: Hawksworth, 1979a), I was working on long-forgotten generic names when I found that Koodersiella pre-dated my chosen name by 70 years. However, Höhnel had mistaken the lichen host as a basal membrane ("hypothallus") of his new fungus (Eriksson and Hawksworth, 1987).

However hard you try; you must accept that your search can never be exhaustive. The leading evolutionary malacologist, Arthur J. Cain (1921-1999), used to compare this search to looking for water babies: "No one has the right to say that no water babies exist, till they have seen no water babies existing.... A thing which nobody ever did, or perhaps will ever do." (Kingsley, 1863). One cannot scour every item of literature, and study every specimen or culture, just as one can never examine every part of all the lakes, rivers and seas on Earth. It is a matter of trying to do the best you can, but also being realistic over the time spent - otherwise, nothing would ever reach publication. This was a lesson Martin B. Ellis (1911-1996) stressed to me as I struggled to find names for unusual microfungi I had collected; his view was that if something had a name, and was well-described, others could then use that name until such time as an earlier one eventually turned up-if it ever did.

I have also found it to be good practice to show copies of illustrations of a potentially new taxon to colleagues. They may know it already, or recall seeing an alreadypublished description of the same fungus. This can add to your confidence that your taxon was indeed new and avoid the embarrassment of having rapidly to relegate your newly-introduced name into synonymy. On the positive side, it can also lead to instances of additional specimens coming to light that colleagues had also collected but, yet, were left as unidentifiable; that situation happened to me several times.

\section{Lesson 2: Examine as many specimens and cultures as you can}

If you just have one or two specimens or cultures of a species, it is difficult to develop a concept of its potential range of variation. Just how important are the slightly longer spores, superficial pruina, branching, or the colours in nature or in culture? 'Tom' Tutin (1908-1987), under whom I studied at the University of Leicester, used to drill into his aspiring plant taxonomists that it was easy to say two species were different if you had two or very few specimens, that things became less clear as more were studied, but when you had studied very many more samples, the situation would become clearer. I have always found this to be true, and no more so than in my work on Bryoria and Lichenoconium. In the case of Bryoria, I remember arranging a long series of specimens on a bench at Kew with 'Ernie' Brodo to be sure there was a continuum in colour in a species that had previously been split into several. In reality it was a single species, and its other names were synonymized (Brodo and Hawksworth, 1977). In Lichenoconium, there had been a tradition of naming species according to their host, but I had lots of unreported hosts, so 


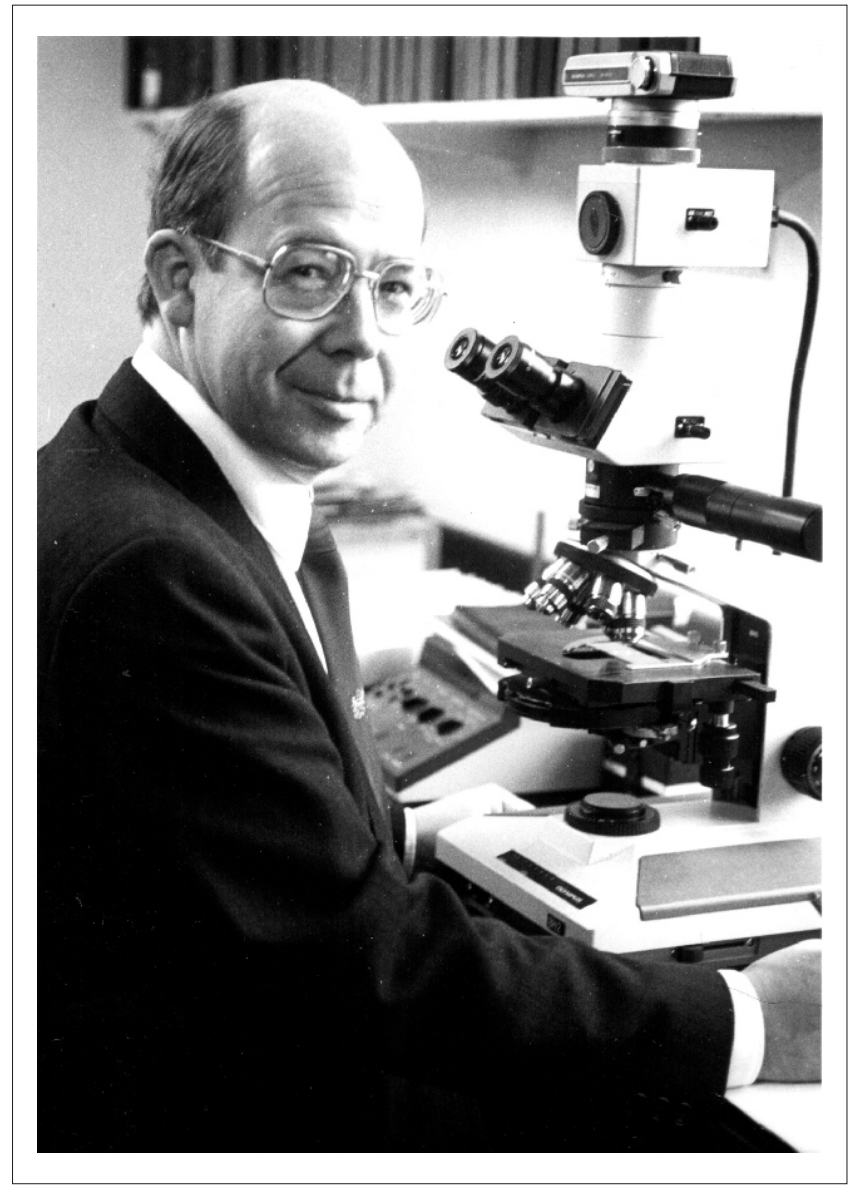

Fig. 2. The author at the microscope as Director, International Mycological Institute, Kew, Surrey, UK, in 1990.

could they all really be new? I filled three folders of drawings and measurements of key characters and found it possible to recognize a limited number of species on the basis of anatomical features; some were host-specific but others were not, and some host species could support as many as three different Lichenoconium species - sometimes at the same time but with different symptoms (Hawksworth, 1977). In the case of many specimens that can be seen by eye and without a hand lens, an excellent way to become familiar with their macroscopic features is to study the taxa in the field. There may be correlations with some environmental factors that could not have been foreseen. For example, in 1973, Ernie and myself witnessed in a Bryoria a continuum in thallus form from tufted to pendulous along a transect from exposed twigs to the sheltered interior of a forest in Quebec making clear this was variation in a single species. Examining cultures under standard conditions can similarly be useful in resolving variations in appearance or pigmentation- as in Monascus where we reduced 15 species to three (Hawksworth and Pitt, 1983). Conversely, if two very similar lichens grow side by side in what appears to be precisely the same habitat, for example two lichens on the same rock, but remain distinct, it is reasonable to assume there are some genetic differences between them.
While it is clear that as many collections as possible should be studied to get an idea of the range of variation in a fungus, that is not to say that you should never describe something as new if you just have a single specimen, slide, or isolate. I did describe one fungus just from a microscope slide in 1973 by virtue of its extraordinarily characteristic ascospores (Hawksworth and Booth, 1973) and later even introduced a new generic name for that single slide, Zopfiofoveola (Hawksworth, 1979). This still has to be refound in nature and I do not commend such a practice. In 1981, I came across a specimen collected in 1907 of what I thought to be a new genus of a lichenicolous fungus growing on Normandina in Tasmania. Subsequently, I spent the next nine years trying to get more material from the same country (and from other countries around the world) from the same host, asking various colleagues to help. This was Globosphaeria (Hawksworth, 1990) which is indeed very rare, but in 1988 it was collected in Washington State in the USA (Diederich, 2003), but it has never been found again in New Zealand (De Lange et al., 2018). Obtaining more material is much easier with distinctive cultures, because at least variation in the cultures can be assessed and many sporophores may be present for study; that was the case with Bimuria (Hawksworth et al., 1979), sequenced many years later and since used extensively in phylogenetic re-constructions in Dothideomycetes.

Lesson 3: Study as many characters with as many techniques as possible in the field as well as the laboratory

I cannot stress too strongly the importance of examining as many features as possible in formulating species concepts. Where possible start in the field, something also valuable for ascertaining variation in a species (Lesson 2) but further, it may be possible to observe features not apparent in dried and squashed fungarium preparations. A classic case is the tropical basidiomycete Cora where specimens on herbarium sheets all look very similar, and were thought to be a single species (Hawksworth, 1988), but numerous morphotypes can be seen in the field and these have now been proved as distinct by molecular work. Now, 87 are formally named in this "species" and the actual number has been predicted to be around 350 (Lücking et al., 2017); how embarrassingly wrong can one be!

New techniques or approaches for examining known characters, or even revealing ones that could not be studied before, should always be taken up in case they can provide insights into the most appropriate classification to adopt. I have always been anxious to take advantage of any available technology. New toys can be real fun, although some may not live up to expectations and be disappointing.

It was with this spirit that I was the first in the UK to use chromatography, first paper and later thin-layer, in the identification of natural products in lichens (Hawksworth, 1968), and the first to use scanning electron microscopy (Hawksworth, 1969), and numerical taxonomy (Hawksworth, 1970) in the systematics of lichen-forming fungi. Later we tried bacterial enzyme strips as a possible aid to identification in Penicillium (Bridge and Hawksworth, 1984), and flow cytometry to reveal chromosome aneuploidy in a species of that genus (Bridge et al., 1986). 
When molecular methods became available, we were also quick to try those, initially in trying to place the human pathogen Pneumocystis, then causing death through pneumonia in most AIDS patients (Wakefield et al., 1992). Methods to facilitate DNA extraction from intact lichen thalli were also worked out (Crespo et al., 1997), and by examining 231 specimens of Parmelia sulcata, something hardly done at that time, finding that different genotypes occurred within a single lichen morphotype (Crespo et al., 1999). I was also intrigued by the potential of cell wall polysaccharides as a systematic tool in fungi as they were much used by bacteriologists and was able to do this to confirm a molecular phylogeny placement of Lichina (Prieto et al., 2008).

In wanting to use new techniques, I have always tried to find appropriately skilled collaborators and get them interested in particular problems. Molecular approaches have become increasingly complex and by working in teams, taxonomies can be tested, and questions posed, as never before. Examples of success in this approach are where I have initiated or contributed to long-standing debates over generic concepts in parmelioid lichens (Crespo et al., 2010), the placement of sterile filamentous lichens (Muggia et al., 2008), and the revelation of a mismatch been chemical and morphological features and molecular data (including data from microsatellites) in the Bryoria fuscescens complex (Boluda et al., 2019).

This Lesson is that If you have an opportunity to try new methods that may shed new light on critical questions, try them, even if no one has used them before - and do not hesitate from trying to get others already skilled in a technique to collaborate with you. In the $21^{\text {st }}$ century, multi-authored papers are now almost the norm and putting together teams may be the only way to harness the necessary human and experimental resources and expertise to address burning questions.

\section{Lesson 4: Formulate species concepts before examining types}

When embarking on a taxonomic revision of a particular group, it is tempting as a first step to obtain all the namebearing types within it. I fell into this trap when starting my $\mathrm{PhD}$ on alectorioid lichens in 1967, and when requesting loans from Uppsala, was quickly reprimanded by one of the world's leading lichenologists of the day, Rolf Santesson (1916-2013). This is corollary of Lesson 2; as some types may not be representative of the range of variation in nature, it is essential first to examine as many samples as possible in order to develop a species concept. Further, types can be extremely small, poorly developed, and fragile. As types are irreplaceable, and the final arbiter in the application of a name, they should not be examined until the latest stage of a study when it is known which characters need to be checked. Some of the most important historic collections are now only allowed to be studied in the holding institution under close supervision, and types in them are not sent out on loan.

Where material is sent on loan, there is the potential for their loss in transit, or even destruction by customs officials at entry points into a country. When visiting the Komarov Botanical Institute in St Petersburg in 1975, this was brought home to me very forcefully. The folder for a type I had requested, but which never had reached me in Kew, contained a note saying it had been sent on loan to me! The specimen was lost to science and as a result, there will always be uncertainty as to the application of that species name and its taxonomic status. When I was Director of the International Mycological Institute, we safe-guarded type material by adopting a policy of sending only a part of the specimen at any one time. If the other parts of the specimen were needed, they were sent to the borrower after the first part was safely received back in our collection.

The time to bring type specimens into a revision is when the generic or species concepts have been resolved, when the appropriate group for the type material can be assigned. Notes from any such examination should be preserved and attached to the material; any microscopic preparations made from a type specimen should be retained as they may be of assistance to future researchers and avoid the need for them to destroy more of the type material. Some old specimens can be remarkably small and fragmentary. For example, a perithecioid ascomycete may have only $2-3$ perithecia or even just a single perithecium left in the specimen. I have encountered this several times as, for example, when resurrecting Phaeosporis (Eriksson and Hawksworth, 1987), or examining three pieces of bark each with a single ascoma of Microthelia dominans. In the latter case, I used one of the three perithecia that remained for microtome sections, all of which were retained (Hawksworth, 1985). It is pivotally important to preserve microscopic preparations from types very carefully so they can be studied by future researchers.

The removal of material from type collections for DNA extraction is now a major issue. While molecular data can potentially resolve the application of names conclusively, it often requires sizeable samples which are inevitably destroyed in the process. Further, while there are some spectacular cases of DNA sequences being recovered from material collected as far back as 1794 (Hawksworth, 2013), this often fails for specimens more than a few years old and so any possible information from the fragment(s) used in the DNA analysis is lost. There is also the issue that if the DNA extract is not properly refrigerated and conserved, additional fresh fragments of the specimen may need to be processed to study other gene sequences.

Fortunately, however, the situation is less critical when extype cultures are available as they provide back-up material for adding to the pool of genetic material used for formulating initial concepts (e.g. Hawksworth and Pitt,1981). It is, however, important to check the history of such isolates as they often pass from collection to collection and may be contaminated. Some of the leading fungal genetic resource collections always keep a separate dried-down culture of the original. This is then available for checking that the identity of the current organism is the same as the one originally deposited.

\section{Lesson 5: Taxonomic ranks are a human construct}

The issue of the application of ranks in the taxonomic hierarchy is a never-ending debate, and there is a huge 
literature on the concept of species. My own library contains nine books on the species concept that have appeared in the last couple of decades alone.

It is important never to forget that the purpose of a name is to facilitate communication about a particular organism, or group of organisms, in an unambiguous way. Notwithstanding the huge literature, and even computer programs to assist decision-making in taxonomic recognition and affiliation, we must remember that names and rankings are human constructs. Many of the debates overlook this fundamental matter.

A mechanistic approach may still be useful, however, and, in pre-molecular times, I tried cluster analysis for alectorioid lichens (Hawksworth, 1970), Chaetomium (Hawksworth and Wells, 1973), and Penicillium (Bridge et al., 1987). More recent approaches rely entirely on the interpretation of molecular data (Lücking et al., 2020) but, if molecular analysis splits a species into two or more, I realized the importance of going back to re-examine other features; for example, we found that a Parmelia we described as new also differed in thallus lobe morphology, ecology, and geographical distribution from the other species with which it had been included (Molina et al., 2004).

Various species-recognition model programs are now available, and these are designed to help in deciding whether species rank should be used. We recently tried several of these programs on the same data set in a species complex of Bryoria (Boluda et al., 2018); but the results were variable and the final decision as to the number of recognized species still came down to us making a reasoned choice. Inevitably, decisions as to rank will always be subjective.

What is critical is to obtain as much data of diverse types as possible so decisions can be based on comprehensive information on biological, morphological and, where possible, molecular characteristics (see Lesson 3). I became particularly interested in this matter when leading a major multidisciplinary team aimed at clarifying species concepts in some critical groups of Penicillium in the pre-molecular mid1980s. I subsequently published my working "pragmatic" species concept (Hawksworth, 1996: 32): "species are groups of individuals separated by inheritable character discontinuities and to which it is useful to give a species name". I was subsequently amused to see this picked up and cited by both botanists (Heywood, 1998) and zoologists (Kunz, 2012: 5).

For further guidance about describing new species of fungi in the molecular age, see Lücking et al. (2020).

The same subjective situation applies to the rank of genus and above, where it is important to be especially sensitive because changes in generic names cause the most confusion and annoyance amongst all who use scientific names. This is, therefore, very much a social responsibility as well as a scientific one, and not to be undertaken lightly. Today the decisions about what is a genus, family, or order, are generally based on separations into different well-supported clades produced from molecular data sets. Up to now, traditions have varied for different groups of fungi. In some cases, mycologists have been content for genera to contain hundreds of species, and then use ranks such as subgenus or section to recognize well-marked clades within them (e.g. Agaricus, Cladonia, Hebeloma). In contrast, others have chosen instead to recognise a large number of genera containing relatively few species (e.g. Boletus s. lat., Caloplaca s. lat., Hygrocybe s. lat.), and not use any intermediate ranks.

In some cases, there have been long-standing and acrimonious arguments, the one on Aspergillus surely being the most notable, and one where most users have been particularly conservative (Samson et al., 2017). If you are unsure what decision to make in a particular case, show your data to others working on the same fungi, and discuss your dilemma with them.

Changes at ranks above genus are of less concern to most users of names but do remember that very many known fungi have yet to be sequenced and that, at best, we may know only around $6 \%$ of those on Earth today (Hawksworth and Lücking, 2018). Consequently, the circumscription of families, orders, and even classes is constantly changing with the advent of new discoveries, so I have become hesitant to name any new families, orders, or even higher taxa.

\section{Lesson 6: Make the international Code work for you}

The International Code of Nomenclature for algae, fungi, and plants (ICNafp; Turland et al., 2018) is designed to promote the stability of names, but full advantage is not always taken of its powers. Various modifications in the ICNafp over the years mean that today if, there is a sound case to be made, since 1993 there is no need to change a name for nomenclatural reasons alone; this power is not always appreciated. When I drew attention to this reality (Hawksworth, 1993a; 1994), I was promptly castigated for bringing notice to this reality by some botanists (Brummitt, 1994).

Now, names of fungi at the rank of family, genus, and species, can be (1) conserved over earlier competing names, (2) placed on a protected list or names, (3) rejected, (4) have the type changed, (5) have an interpretative epitype designated, or (6) have the spelling fixed. Further, whole books which include taxonomy can now be placed on a list of suppressed works, with all names and typifications in them in particular categories excluded from consideration. The process to be followed to achieve these results is, however, lengthy; a proposal has to be published in Taxon, commented on, voted on by the Nomenclature Committee for Fungi (now appointed by each International Mycological Congress), and their opinion approved by the General Committee on Nomenclature (appointed by each International Botanical Congress). This procedure can take several years and so may deter researchers keen to publish their new taxonomy from following this route. However, authors are empowered under the ICNafp, to continue to maintain the existing usage of names while proposals are under consideration. Consequently, if that is stated in a publication, this justifies a researcher retaining established names and so removes the need to delay publication. This was done in the study of Boluda et al. (2019) where conservation of one species name 
over another 13 earlier names was proposed separately (Hawksworth et al., 2019) and the established name retained while a decision from the Committee is awaited.

Over the years, I have made or contributed to 31 proposals to safeguard names using these various procedures, several dealing with batches of names, and almost all were accepted. I have learnt that if such proposals are carefully researched and forcefully argued, and especially if also supported by several colleagues from different countries, they will probably be accepted.

I have also learnt that in ICNafp if a case is sound, whole rules can be deleted or modified, even in the face of initially hostile resistance. With persistence, a dream can become a reality. A notable example is the end of the separate naming of the different morphs of the same fungus - this took 37 years. It took 32 years to delete all special provisions made for lichenforming fungi, and 30 for the use of the ":" in citations of sanctioned names to be abandoned (Hawksworth, 2018). I hope I live to see the year when the much-needed naming of fungi only known from DNA in environmental samples becomes regularized, a journey that was initiated in 2016 (Hawksworth et al., 2016)!

\section{Lesson 7: Always deposit isotypes and preserve vouchers for unusual records}

It is possible to base new scientific names on very limited material (Lesson 2), but that is far from ideal. If a name is based on specimens, and if there is sufficient material, it is wise to split the collection, keep part as the holotype in one institution, and deposit one or more duplicates (isotypes) in different one(s). I aim to deposit holotypes of the fungi I describe in the country in which they were collected so they can be a resource accessible to local researchers, with isotypes in one of the major international fungaria. This is especially important today when there are increasing concerns over the ownership of natural biological resources, the import of biological materials, and secure shipping costs. The existence of isotypes means that if a holotype is lost or destroyed, there is still material available to fix the application of the name. There are cases where the importance of collections has not always been appreciated by those responsible, and type material has been destroyed. In some instances, major collections have been entirely or almost entirely lost in military actions or fires.

The retention of vouchers for published or databased records resulting from fieldwork, or used in any experimental studies, is critical. This is especially important for rarely collected fungi, or ones discovered in areas where they are not expected to be found. This came home to me forcefully early in my career when I recorded Cyphelium inquinans from several sites in the Scottish Highlands in 1968. I had not collected any vouchers, as it was a species I knew well from central England, so my records were omitted from the first map of its distribution in the UK (Bailey, 1974). Subsequent fieldwork revealed that the species was actually characteristic of ancient pinewoods in Scotland so the records could be re-instated (Seaward and Hitch, 1982). In conducting my long-term survey of the fungi of a nature reserve in south-west England,
I endeavored to preserve at least one voucher of every species found, though not of every find (Hawksworth, 1976). This has been most important as when others have questioned some of my records that appeared unusual to them, there were specimens for them to examine to substantiate or correct my identifications.

Another reason to ensure vouchers are retained is that not only names, but species concepts can change over the years; names can be found to have been misapplied, or single species can be segregated into more than one. This means that some records lose all their value and just have to be ignored in assessments of species distributions. I am always reminded of the comment of R.W.G. Dennis (1911-2003), a most meticulous collector all his life: "Lists of records that cannot be verified are mere waste-paper" (Dennis, 1960: xxii).

The situation with living cultures is similar. In numerous experimental and biochemical studies, the cultures are discarded and not preserved. At least today, leading mycological journals require all (or representative ones if there are very many) to be permanently preserved in a genetic resources collection of cultures. They can then be made available to anyone wishing to confirm results or conduct additional experiments on the same strains.

In a case where a new fungus is described from culture, and the holotype is living, the ICNafp now requires that it must be permanently preserved in a metabolically inactive state. Similarly preserved duplicate cultures can then been deposited in other collections around the world as isotypes. This is easier to do when there is plenty of material of the type. Ex-type cultures can be generated and supplied when required from metabolically inactive vials but, in some cases, the originals may no longer be viable, or they may become contaminated. When describing fungi from culture, I have always been conscious of this and aimed to deposit them in several institutions on different continents. This was the case in Bimuria novae-zelandiae (Hawksworth et al., 1979; see also p. 3), where the culture deposited in IMI (now CABI Bioscience) was lost; but it had also been preserved in CBS, and cultures are still available from there today. On the other hand, I learnt recently that the voucher culture I had deposited at IMI of one of the first lichenicolous fungi cultured, Sclerococcum sphaerale (Hawksworth and Jones, 1981), had become contaminated; in that case I had not had the foresight to send a duplicate culture to another collection.

\section{Lesson 8: Check measurements of microscopic features}

This Lesson may seem obvious, but I have found there are several important, though often untaught, lessons. I became particularly conscious of issues over measurements during my examination of the type collections of names in Microthelia (Hawksworth, 1985). In many cases, the measurements I made were in agreement with those published when the species was originally described, even after conversion from the original units in which they were made; some of those now seem somewhat exotic, such as hundred thousandths of an imperial (or Paris) inch or line. In many other cases there were discrepancies which suggested something more fundamental was wrong, and these could 


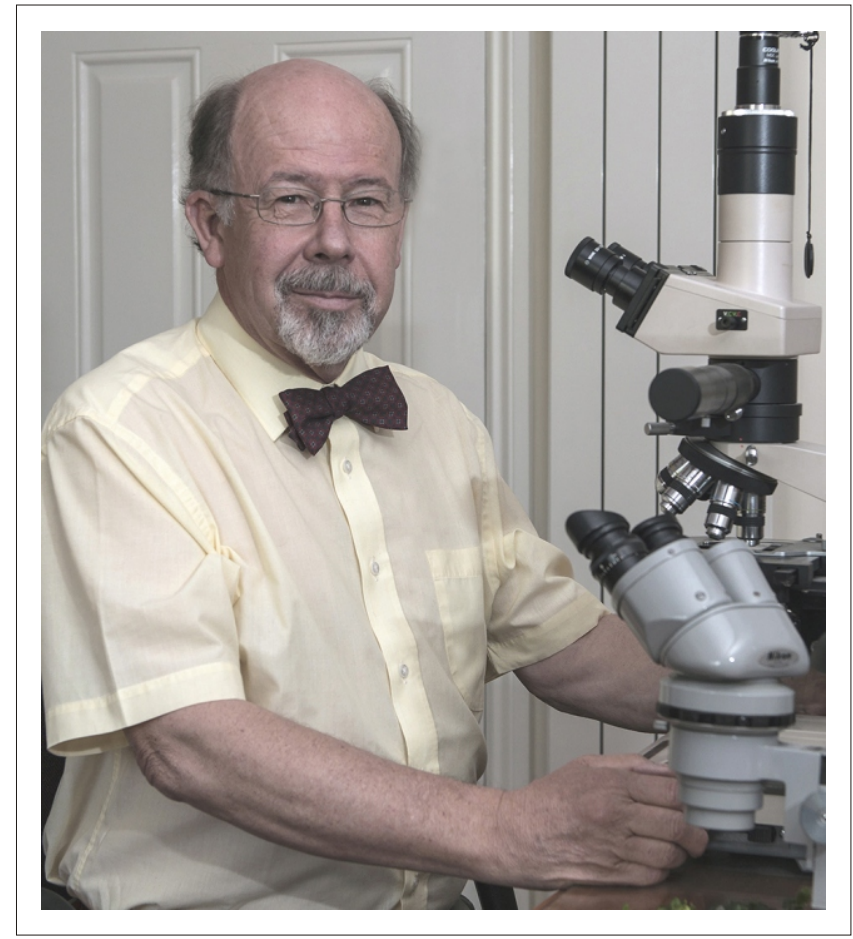

Fig. 3. The author at the microscope in his home laboratory in Ashtead, Surrey, UK, in 2013.

only be explained by errors in calibration or measurement. In one particular work (Mudd, 1861), it had been known for many years that the measurements were "inaccurate" (Hawksworth and Seaward, 1977), and a conversion factor has since been calculated (Kocourková and Knudsen, 2010). This indicated that this was an issue of microscope calibration. For most authors' works, however, such detailed analyses and conversion factors are not available.

Calibration is critical, so be sure that the microscope you use is calibrated using a scale on a graduated slide. This is important even if you have a digital link to a computer, as I have found that automatically made measurements may also need to be verified in the same way; the default positions may not be appropriate for your particular optical set-up. The values need to be calculated for each eyepiece/objective combination and, as the rules on both the slide and the eyepiece/screen have a thickness, there will inevitably be some subjectivity in this process. In order to avoid any illusions of accuracy, for publication it is a common practice to round measurements, for example to the nearest $0.5 \mu \mathrm{m}$.

Another factor that can affect measurements is the mounting medium and stain. There are very few studies on this, but it was an issue which concerned me considerably. Five fungi with different spore characteristics were subjected to 13 different mounting and staining techniques and then measured (Oliver et al., 1987). We found that thin walled, colourless spores were much more affected than ones with thick melanized walls, and the mountants of most concern were $40 \% \mathrm{KOH}$ (which tends to swell spores), and lactophenol cotton blue without heat (which tends to shrink them). Water is probably the best for reproducibility of measurements worldwide, but it is not suited to visualizing all details of interest or making permanent preparations. From this study I learnt that when carrying out any comparative study, it is critical to always use a single mountant/staining regime, and also to state this in the resultant publication. More comprehensive comparative studies of the effects of different mountants on spore sizes would be most helpful.

Measurements should always be made through the eyepiece rather than from drawings made with a camera lucida or drawing tube. I learnt that lesson when Martin Ellis (see above) became concerned when his ranges of measurements of fungi described by another mycologist at Kew were different. It emerged that the other mycologist (not me!) had been making camera lucida drawings and measuring the spores with a ruler to obtain sizes which he had included in his publications. There will always be distortion with measurements made in this way the more distance there is from the centre of the field of view using such drawing aids.

The key Lesson here is not to assume measurements reported in a paper are precise, and that if mountants are specified also to use those in any slides prepared from other material with which they are to be compared.

In measuring structures, I always try and find the largest and smallest of fully developed features, and then aim to measure a minimum of ten. This can be hard work in some fungi, although easy with others. It is helpful to indicate the number of structures measured after a particular measurement, for example as " $(n=10)$ ". In the case of spores, I now always try to indicate the ranges of the length: breadth ratios also as these can be quite instructive (e.g. Doré et al., 2006).

\section{Lesson 9: Do not be afraid to challenge current ideas and present new hypotheses}

Science proceeds incrementally by a process of hypotheses being put forward, tested by evidence available at the time, and then challenged repeatedly in the future as new data sets are generated. I always enjoy working with students as, on occasion, they pose questions, and look at issues, in novel ways that challenge the current accepted wisdom.

Each new scientific name can be viewed as a hypothesis. It is a statement that a fungus is new to science or has a particular place in the Tree of Life. The true novelty of its position will be challenged over the years as similar species are discovered, and as molecular data become available. Some names will sink into synonymy, and just become part of the historical burden of unused names (see Lesson 1), while others will stand the test of time and become well used. For example, a generic name originally introduced for a single species, might have many more added to it over the years, as in Weddellomyces; this has swollen from one to 14 species since I first introduced it in 1986 (Hawksworth, 1986).

Perhaps the most fundamental challenge I have championed was the integration of the classification of lichen-forming fungi into a single system with all other fungi. It is hard to understand now, but when I started my journey in taxonomy, lichens were generally placed in a separate class, Lichenes! When all generic names proposed for lichens were first 
included in Ainsworth \& Bisby's Dictionary of the Fungi (Ainsworth et al., 1971), and newly published names of these fungi started to be catalogued in the Index of Fungi that same year, I could hardly believe the almost hate-mail and verbal abuse I received from some plant pathologists and lichenologists! Yet almost three decades later, especially with reinforcement from molecular phylogenetic reconstructions, it was impossible even to contemplate separate classifications. Now, almost 50 years later, that they could ever have been separated seems hard for the current generation to understand. Even single genera are now accepted as including species which are lichenized and others which are not, and some single species are now known that are facultatively lichenized.

From the analysis of different data sets (Hawksworth, 1991), I formed the hypothesis that there are at least 1.5 million species of fungi on Earth. This was also met with great skepticism from some mycologists and other biologists (e.g. May, 1991) as the figure was after all, six times the greatest number previously suggested, and 23 times that in the then current Dictionary (Hawksworth et al., 1983). That figure was introduced as being a conservative estimate, and it has proved to be exceptionally so, with a new working estimate of 2.2-3.8 million species now commended (Hawksworth and Lücking, 2018). Some more recent environmental DNA work, however, suggests a staggering 12 million species (Wu et al., 2019).

But all hypotheses will not prove to be sound. For example, I suggested that the numbers of co-evolved lichenicolous fungi in different lichen-forming families was correlated with different ascus types, and that Peltigerales could be ancestral even to some other ascomycete groups (Hawksworth, 1982); further support for that hypothesis appeared to come from a graphic analysis of the ecology of the then accepted orders (Dick and Hawksworth, 1985). Molecular work has shown just how wrong one can be, with the extant lichenized fungi appearing as derived from those of other biologies (Nelsen et al., 2019). As a scientist I welcome such testing as our hypotheses need to be robust and able to withstand, and be reenforced by, new data and analyses, and not mislead. If I find I have made mistake, I always try to correct it as soon as the opportunity arises in print to help prevent erroneous "facts" becoming established.

Lesson 10: Do not submit your paper right away and choose an appropriate journal

I have found that when I write anything, invariably, it can be improved when I return to the draft some days or weeks later. It is not only an issue of presentation and style; in reviewing one's own work, additional points jump out, and additional references or data can be cited to strengthen an interpretation. If I have something that may be controversial, or I need to be confident that my interpretations are justified, I also like to ask colleagues and my wife to comment on my drafts. This is especially important as the meaning of a sentence may be perfectly clear to me, but not to another reader.

I also try and view my drafts through the eyes of a potential referee or editor, striving to make my papers referee-proof prior to submission. When reviews and comments are received, they can be most helpful picking up points I had not previously considered and drawing attention to papers I should have seen or cited. In some cases, the referees are incorrect in their criticisms, and this can be irritating, but justification can often be made directly to the editor.

In choosing a journal for submission, my policy is to select one that seems most appropriate for the subject matter. As a result, my publications appear in journals ranging from ones of very local interest (e.g. Hawksworth, 1993b) to the regional (e.g. Abu-Zinada et al., 1986), the specifically mycological (e.g. Hawksworth, 1991), and the interdisciplinary international (e.g. Hawksworth and Kirk, 1995). The better the fit of a paper to the scope of a journal, the more likely it is to be considered for publication.

There are two major issues that have emerged over the last two decades which did not impinge on me during my employed career. One is the proliferation of electronic journals, and the other is the stress placed on journal impact factors in assessing an individual person's performance - and even salary.

The rise of new electronic online-only journals (even in the case of those that are strictly mycological), has been dramatic so that, today, almost anything can be published almost regardless of quality - as long as an article processing charge (APC) is paid. This situation is particularly unfortunate for those without an institution or university department behind them that is willing and able to pay. Now as a "retired" researcher, I aim to submit to long-established journals, having a sound refereeing process, that do not charge an APC (unless I have a co-author who is fortunate to have access to such funds).

\section{CONCLUSIONS}

Characteristically, a scientist has an enquiring mind, is always learning, and is, in effect, a perpetual student. This is especially true for taxonomic and systematic work as, over the years, an endless variety of specimens arrives for study on our benches and microscope stages. We are continually learning while being fascinated by the immense variety of the fungal world.

I have been fortunate to live and work through an exciting period in mycology which has witnessed a series of extraordinary developments (Crous et al., 2015), and I am confident there are more to come as we become increasingly familiar with fungal genomes and learn how to interpret them.

My aspiration is that this synopsis of some of the Lessons I have learned over the last 50 years may prove of some value to those embarking on the exploration of the World's fungi. This is a fascinating journey to take, when one never knows what novel organisms will suddenly appear on a slide as you peer down a microscope; you may see a fungus that no-one has ever seen before. In my case this journey started while at school, and I was keen to identify fungi, initially lichenformers, encountered on field courses. I never imagined that my taxonomic road would prove to have side turnings leading to contributions to aspects of air quality bioindication, biocontrol, biodeterioration, bioprospecting, conservation of 
biodiversity, criminal and civil forensic investigations, indoor fungi, industrial mycology, medical mycology, palaeoecology, plant pathology, and symbiotic associations.

There is perhaps a further Lesson here, that taxonomy is not just an esoteric discipline but has a critical role in diverse areas of human concern. The extent of the unexplored fungal kingdom is so vast that the opportunities for discovery, and to make contributions to diverse fields, is truly enormous.

\section{ACKNOWLEDGEMENTS}

This contribution was inspired by discussions on various taxonomic issues with Indian mycologists on the occasion of the 45th Annual Meeting of the Mycological Society of India in Pune on 19-21 November, 2018. The meeting was organized by the Agharkar Research Institute, and I am indebted to its Director, Kishorwe M. Paknikar, the Society's President Kandikere R. Sridhar, and Meeting Organizer Sanjay K. Singh for enabling my wife (Patricia E. J. Wiltshire) and I to participate in what was a most enjoyable and stimulating occasion.

I have benefitted enormously from what I have learnt from a cadre of distinguished mycologists and other systematists over the years, many of whom are mentioned in this text. These include the late Professor C. V. Subramanian, founder of the Mycological Society of India and also the journal Kavaka being Transactions of Mycological Society of India. I dedicated my presentation in Pune to him; this concerned the macrofungal resource and was based on an article then already in press elsewhere (Hawksworth, 2019).

Finally, I am especially grateful to my wife for her painstaking and critical revision of this text prior to submission.

\section{REFERENCES}

Abu-Zinada, A.H., Hawksworth, D.L. and Bokhary, H.A.1986. The lichens of Saudi Arabia, with a key to the species reported. Arab Gulf Journal of Scientific Research, Special Publication 2: 1-54.

Ainsworth, G.C., James, P.W. and Hawksworth, D.L. 1971. Ainsworth \& Bisby's Dictionary of the Fungi. 6th edition. Kew: Commonwealth Mycological Institute.

Bailey, R.H. 1974. Distribution maps of lichens in Britain. Map 8. Cyphelium inquinans. Lichenologist 6: 169-171.

Bisby, G.R. 1945. An Introduction to the Taxonomy and Nomenclature of Fungi. Kew: Imperial Mycological Institute.

Boluda, C.G., Rico, V..J, Divakar, P.K., Nadyeina, O., Myllys, L., McMullin, R.T., Zamora, J.C., Scheidegger, C. and Hawksworth, D.L. 2019. Evaluating methodologies for species delimitation: the mismatch between phenotypes and genotypes in lichenized fungi (Bryoria sect. Implexae, Parmeliaceae). Persoonia 42: 75-100.

Bridge, P.D. and Hawksworth, D.L. 1984. The API ZYM enzyme testing system as an aid to the rapid identification of Penicillium isolates. Microbiological
Sciences 1: 232-234.

Bridge, P.D., Hawksworth, D.L., Kozakiewicz, K., Onions, A.H.S., Paterson, R.R.M., Sackin, M.J. and Sneath, P.H.A. 1989. A reappraisal of the terverticillate penicillia using biochemical, physiological, and morphological features. I. Numerical taxonomy. Journal of General. Microbiology 135: 2941-2966.

Bridge, P.D., Hudson, L., Hawksworth, D.L. and Bridge, D.A. 1986. Variation in nuclear DNA content in an ex-type isolate of Penicillium measured by continuous flow microfluorimetry. FEMS Microbiology Letters 37: 241-244.

Brodo, I.M. and Hawksworth, D.L. 1977. Alectoria and allied genera in North America. Opera Botanica 42: 1164.

Brummitt, R.K. 1994. What did we think we were voting for at Tokyo? The Linnean 10(2): 13-15.

Crespo, A., Bridge, P.D. And Hawksworth, D.L. 1997. Amplification of fungal rDNA-ITS regions from non-fertile specimens of the lichen-forming genus Parmelia.Lichenologist 29: 275-282.

Crespo, A., Bridge, P.D., Hawksworth, D.L., Grube, M. and Cubero, O.F. 1999. Comparison of rRNA genotype frequencies of Parmelia sulcata from long established and recolonizing sites following sulphur dioxide amelioration. Plant Systematics and Evolution 217: 177-183.

Crespo, A., Kauff, F., Divakar, P.K., del Prado, R., PérezOrtega, S., Amo de Paz, G., Ferencova, Z., Blanco, O., Roca-Valiente, B. , Núñez-Zapata, J., Cubas, P., Argüello, A., Elix, J.A., Esslinger, T.L., Hawksworth, D.L., Millanes, A., Molina, C., Wedin, M., Ahti, T., Aptroot, A., Barreno, E., Bungartz, F., Calvelo, S., Candan, M., Cole, M., Ertz, D., Goffinet, B., Lendemer, J., Lindblom, L., Lücking, R., Lutzoni, F., Mattsson, J-E, Messuti, M.I., Miadlikowska, J., Piercey-Normore, M., Rico, V.J., Sipman, H.J.M., Schmitt, I., Spribille, T., Thell, A., Thor, G., Upreti, D.L. and Lumbsch, H.T. 2010.Phylogenetic generic classification of parmelioid lichens (Parmeliaceae, Ascomycota) based on molecular, morphological and chemical evidence. Taxon 59: 1735-1753.

Crous, P.D., Hawksworth, D.L. and Wingfield, M.J. 2015. Identifying and naming plant pathogenic fungi: past, present, and future. Annual Review of Phytopathology 53: 247-267.

Davis, P.H. and Heywood, V.H. 1963. Principles of Angiosperm Taxonomy. Edinburgh: Oliver \& Boyd.

de Lange, P., Blanchon, D., Knight, A., Elix, J.A., Lucking, R., Frogley, K., Harros, A., Cooper, J.and Rolfe, J.R. 2018. Conservation Status of New Zealand indigenous lichens and lichenicolous fungi. Wellington: Department of Conservation.

Dennis, R.W.G. 1960. British Cup Fungi and their Allies; an 
introduction to the ascomycetes. London: Ray Society.

Dick, M.W. and Hawksworth, D.L. 1985.A synopsis of the biology of the Ascomycotina. Botanical Journal of the Linnean Society of London 91: 175-179.

Diederich, P. 2003. New species and new records of American lichenicolous fungi. Herzogia 16: 41-90.

Doré, C., Cole, M.S. and Hawksworth, D.L. 2006. Preliminary statistical studies of the infraspecific variation in the ascospores of Nesolechia oxyspora growing on different genera of parmelioid lichens. Lichenologist 38: 425-343.

Eriksson, O.E. and Hawksworth, D.L. 1987. Notes on ascomycete systematics. Nos. 225-463. Systema Ascomycetum 6: 111-165.

Hawksworth, D.L. 1968. A note on the chemical strains of the lichen Ramalina subfarinacea. Botaniska Notiser 121: 317-320.

Hawksworth, D.L. 1969. The scanning electron microscope. An aid to the study of cortical hyphal orientation in the lichen genera Alectoria and Cornicularia. Journal de Microscopie 8: 753-766.

Hawksworth, D.L. 1970. Systematic Studies on the Lichen Genus Alectoria Ach. with particular reference to the British Species. 2 vols. PhD thesis, University of Leicester.

Hawksworth, D.L. 1974. Mycologist's Handbook: an introduction to the principles of taxonomy and nomenclature in the fungi and lichens. Kew: Commonwealth Mycological Institute.

Hawksworth, D.L. 1976. The natural history of Slapton Ley Nature Reserve X. Fungi. Field Studies 4: 391-439.

Hawksworth, D.L. 1977.Taxonomic and biological observations on the genus Lichenoconium (Sphaeropsidales). Persoonia 9: 159-198.

Hawksworth, D.L. 1979a The lichenicolous hyphomycetes. Bulletin of the British Museum (Natural History), Botany 6: 183-300.

Hawksworth, D.L. 1979b. Ascospore sculpturing and generic concepts in the Testudinaceae (syn. Zopfiaceae). Canadian Journal of Botany 57: 91-99.

Hawksworth, D.L. 1981. The lichenicolous coelomycetes. Bulletin of the British Museum (Natural History), Botany 9: 1-98.

Hawksworth, D.L. 1982. Co-evolution and the detection of ancestry in lichens. Journal of the Hattori Botanical Laboratory 52: 323-329.

Hawksworth, D.L. 1985. A redisposition of the species referred to the ascomycete genus Microthelia. Bulletin of the British Museum (Natural History), Botany 14: 43-181.

Hawksworth, D.L. 1986. Notes on British lichenicolous fungi: V. Notes from the Royal Botanic Garden
Edinburgh 43: 497-519.

Hawksworth, D.L. 1988. A new name for Dictyonema pavonium (Swartz) Parmasto. Lichenologist 20: 101.

Hawksworth, D.L. 1990. Globosphaeria, a remarkable new pyrenomycete on Normandina from Tasmania. Lichenologist 22:301-305.

Hawksworth, D.L. 1991. The fungal dimension of biodiversity: magnitude, significance, and conservation. Mycological Research 95: 641-655.

Hawksworth, D.L. 1993a. Name changes for purely nomenclatural reasons are avoidable. Systema Ascomycetum 12: 1-6.

Hawksworth, D.L. 1993b. Fungi recorded in the Ruislip Woods. Journal of the Ruislip and District Natural History Society 29: 3-26.

Hawksworth, D.L. 1994. It is no longer necessary to change botanical names in most ranks for non-taxonomic reasons. The Linnean 10(1): 12-15.

Hawksworth, D.L. 1996. Microbial collections as a tool in biodiversity and biosystematic research. In: Culture Collections to Improve the Quality of Life (Eds.: Samson, R.A., Stalpers, J.A., van der Mei, D. and Stouthamer, A.H.): 26-35. Baarn: Centraalbureau voor Schimmelcultures.

Hawksworth, D.L. 2013. The oldest sequenced fungal specimen. Lichenologist 45: 131-132.

Hawksworth, D.L. 2018. Colectomy successful, but nomina sequentia mark time. IMA Fungus 9: (47)-(48).

Hawksworth, D.L. 2019. The macrofungal resource: extent, current utilization, future prospects, and challenges. In: Advances in Macrofungi: Diversity, Ecology and Biotechnology (Eds.: Sridhar, K.R. and Deshmukh, S.K.): 1-9. Boca Raton: CRC Press.

Hawksworth, D.L., Ahti, T., Myllys,L. and Boluda, C.G. 2019. (2675) Proposal to conserve Alectoria fuscescens (Bryoria fuscescens), nom. cons., against the additional names Usnea implexa, Alectoria capillaris, A. cana, A. rubens, A. fuscidula, A. degenii, $A$. forissii, A. ostrobotniae, $A$. kuemmerleana, A. haynaldiae, A. achariana, A. lanestris, A. prostratosteola and $A$. viridescens (Fungi, Ascomycota, Lecanorales, Parmeliaceae). Taxon 68: 400-402.

Hawksworth, D.L. and Booth, C. 1973. A revision of the genus Zopfia Rabenh. Mycological Papers 135: 138 .

Hawksworth, D.L. and Booth, C. 1976. Some observations on Nectria heterospora. Mycologia 68: 195-200.

Hawksworth, D.L., Hibbett, D.S., Kirk, P.M. and Lücking, R. 2016. (308-310) Proposals to permit DNA sequence data to serve as types of names of fungi. Taxon $\mathbf{6 5}$ : 899-900.

Hawksworth, D.L. and Jones, D. 1981. Sclerococcum 
sphaerale obtained in pure culture. Transactions of the British Mycological Society 77: 485-489.

Hawksworth, D.L. and Kirk, P.M. 1995. Passing round the standards. Nature 378: 341.

Hawksworth, D.L. and Lücking, R. 2018. Fungal diversity revisited: 2.2 to 3.8 million species. In: The Fungal Kingdom (Eds.: Heitman, J., Howlett, B.J., Crous, P.W., Stukenbrock , W.H., James, T.Y. and Gow, N.A.R.): 79-95. Washington DC: American Society for Microbiology.

Hawksworth, D.L. and Pitt, J.I. 1983. A new taxonomy for Monascus species based on cultural and microscopical characters. Australian Journal of Botany 31: 51-61.

Hawksworth, D.L. and Seaward, M.R.D. 1977. Lichenology in the British Isles 1568-1975: an historical and bibliographic survey. Richmond: Richmond Publishing.

Hawksworth, D.L., Sutton, B.C. and Ainsworth, G.C. 1983. Ainsworth \& Bisby's Dictionary of the Fungi. 7th edn. Kew: Commonwealth Mycological Institute.

Hawksworth, D.L. and Wells, H. 1973.Ornamentation of the terminal hairs in Chaetomium Kunze ex Fr. and some allied genera. Mycological Papers 134: 1-24.

Hawksworth, D.L., Yen, C.C. and Sheridan, J.E. 1979. Bimuria novae-zelandiae, gen. et sp. nov., a remarkable ascomycete from a New Zealand barley field. New Zealand Journal of Botany 17: 267-273.

Heywood, V.H. 1998. The species concept as a socio-cultural phenomenon - a source of the scientific dilemma. Theoretical Biology 117: 203-212.

Kingsley, C. 1863.The Water Babies. London: Macmillan.

Kocourková, J. and Knudsen, K. 2010. Converting Mudd into microns. British Lichen Society Bulletin 107: 50-51.

Kunze, W. 2012. Do Species Exist? Principles of taxonomic classification. Weinheim: Wiley-Blackwell.

Lücking, R., Dal Forno, M., Moncada, B., Coca, L.F., VargasMendoza, L.Y., Aptroot, A., Arias, LJ, et al. 2017. Turbo-taxonomy to assemble a megadiverse lichen genus: seventy species of Cora (Basidiomycota: Agaricales: Hygrophoraceae), honouring David Leslie Hawksworth's seventieth birthday. Fungal Diversity 84: 139-207.

Lücking, R., Aime, M.C., Robbertse, B., Miller, A.N., Ariyawansa, H.A., Aoki, T. Cardinali, G., Crous, P.W., Druzhinina, I.S., Geiser, D.M., Hawksworth, D.L., Hyde, K.D., Irinyi, L., Jeewon, R., Johnston, P.R., Kirk, P.M., Malosso, E., May, T.W., Meyer, W., Öpik, M., Robert, V., Seifert, K.A., Stadler, M., Thines, M., Vu D., Yurkov, A.M., Zhang, N. and Schoch, C.L. 2020.Unambiguous identification of fungi: current status and guidelines. IMA Fungus 11(14): 1-32.
May, R.M. 1991. A fondness for fungi. Nature 352: 475-476.

Molina, M.C., Crespo, A., Blanco, O., Lumbsch, H.T.and Hawksworth, D.L. 2004. Phylogenetic relationships and species concepts in Parmelia s. str. (Parmeliaceae) inferred from nuclear ITS rDNA and $\beta$-tubulin sequences. Lichenologist 36: 37-54.

Mudd, W. 1861. A Manual of British Lichens. Darlington: W. Mudd.

Muggia, L., Hafellner, J., Wirtz, N., Hawksworth, D.L. and Grube, M. 2008. The sterile microfilamentous lichenized fungi Cystocoleus ebeneus and Racodium rupestre are relatives of plant pathogens and clinically important dothidealean fungi. Mycological Research 112: 51-57.

Nelsen, M.P., Lücking, R., Boyce, C.K., Lumbsch, H.T. and Ree, R.H. 2019. No support for the emergence of lichens prior to the evolution of vascular plants. Geobiology 18: 3-13.

Oliver, E.M., Bridge, P.D. and Hawksworth, D.L. 1987. The effect of selected mountants and stains on the measurement of fungal spores. Mycopathologia 97: 165-172.

Prieto, A., Leal, J.A., Bernabe, M. and Hawksworth, D.L. 2008. A polysaccharide from Lichina pygmaea and $L$. confinis supports the recognition of Lichinomycetes. Mycological Research 112: 381-388.

Samson, R.A., Huba, V., Varga, J., Houbraken, J., Hiong, S-B, et al. 2017. Response to Pitt \& Taylor 2016: conservation of Aspergillus with A. niger as the conserved type is unnecessary and potentially disruptive. Taxon 66: 1439-1446.

Seaward, M.R.D. and Hitch, C.J.B. 1982. Atlas of the Lichens of the British Isles. Vol.1. Cambridge: Institute of Terrestrial Ecology.

Turland, N.J., Wiersema, J.H., Barrie, F.R., Greuter, W., Hawksworth, D.L., Herendeen, P.S., Knapp, S., Kusber, W.H., Li, D.Z., Marhold, K., May, T.W., McNeill, J., Monro, A.M., Prado, J., Price, M.J. and Smith, G.F. (Eds.) 2018. International Code of Nomenclature for algae, fungi, and plants (Shenzhen Code) adopted by the Nineteenth International Botanical Congress Shenzhen, China, July 2017. [Regnum Vegetabile No.159.] Glashuitten: Koeltz Botanical Books.

Wakefield, A..E, Peters, S.E., Banerji, S., Bridge, P.D., Hall, G.S., Hawksworth, D.L., Guvier, L.A., Alan, A.G. and Hopkins, J.M. 1992. Pneumocystis carinii shows DNA homology with the ustomycetous red yeast fungi. Molecular Microbiology 6: 1903-1911.

Wu, B., Hussain, M., Zhang, W., Stadler, M., Liu, X. and Xiang, M. 2019. Current insights into fungal species diversity and perspective on naming the environmental DNA sequences of fungi. Mycology 10 (3): 127-140. 